\title{
Clinical and epidemiological study of skin cancer in Japan
}

\author{
Masamitsu Ichihashi ${ }^{1}$, Masato Ueda ${ }^{1}$, Tooru Nagano', Keishi Araki ${ }^{1}$, Yoshiyuki Ohno ${ }^{2}$ Santoso Comain $^{3}$
}

\begin{abstract}
Abstrak
Untuk.menentukan prevalansi dan insidensi kanker kulit dan lesi prekanker (actinic keratcsis) dari pcpulasi Jepang, kami memulai pemeriksaan kanker kulit di Kota Kasai (34 56' LU) dan Pulau le (25 JO' LU), pada tahun 1992 -1993. Radiasi sinar matahari pertahun di Pulau le diharapkan yang tertinggi di Jepang. Pada makalah ini, kami akan mempresentasikan hasil pene!itian kanker kulit baik di Kota Kasai maupun di Pulau le, masing-masing sejak 1992 sampai 1997 dan sejak 1993 sampai 1997. Di Kota Kasai, ditemukan 128 kasus keratosis aktinik (KA), 3 kasus karsinoma sel basal (KSB). dan 1 kasus karsinoma sel skuamosa (KSS), yang diidentifikasi secara klinik dan histopatologik. Sedangkan di Pulau le, ditemukan 130 kasus KA, 9 kasus KSB dan 2 kasus KSS. Prevalansi KA per 100.000 penduduk pertahun di Kota Kasai pada tahun 1992-1997 adalah masing-masing 413,4, 291,2, 203,7, 86,8 123,1 dan JOl ,8. Walaupun demikian, jumlah KA di Pulau le pada tahun 1993-1997 adalah masing-masing 1.159,4, 572,8, 1.014,3, 988,9 dan 612,5. Angka-angka di Pulau le secara bermakna lebih tinggi dari angka-angka di Kota Kasai. Rasia Odds yang disesuaikan terhadap umur setiap tahun untuk KA adalah masing-masing 2,79, 1,38, 2,45, 2,39 dan 2,01. Nilai rata-rata prevalansi kanker kulit non melanoma (KKNM KSB dan KSS) di Pulau le pada periode penelitian adalah 50,0 untuk pria dan wanita. Total kasus KSB dan KSS di Kota Kasai pada tahun 1992-1997 adalah masing-masing 1 dan 3,jumlah yang terlalu kecil untuk dapat menghitung prevalansi dan insidensi KKNM. penderita dengan keratosis seboroik (KS) diatas 6 menunjukkan prevalansi yang lebih tinggi daripada penderita lain dengan KS dibawah 5. Hasil ini menindikasikan adanya relasi inversi yang kuat antara prevalansi dan insidensi prakanker dengan garis lintang pada populasi Jepang. Prevalansi KKNM di Pulau le yang sama tingginya dengan prevaiansi pada orang Jepang yang tinggal di Hawai menunjukkan insidensi KKNM yang lebih tinggi di bagian Utara Jepang, dimana kadar ozan akan sangat berkurang di masa yang akan datang. Kulit tipe 1 dan penderita dengan KS ganda diduga sebagai faktor risiko kanker kulit pada populasi Jepang.
\end{abstract}

\begin{abstract}
In order to determine the prevalence and incidence of skin cancer, and pre-cancer lesions (actinic keratosis) of Japanese we started skin cancer examination at Kasai City $\left(34^{\circ} 56^{\prime} \mathrm{N}\right)$ and le Island $\left(2^{\circ} \mathrm{JO} \mathrm{O}^{\prime} \mathrm{N}\right)$ in 1992 and 1993, respectively. Annual solar radiation in le island is expected to be highest in Japan. Here, we will present the results of skin cancer examination in both Kasai City and le Island during 1992 through 1997, and during 1993 through 1997, respectively. In Kasai City, a total of 128 actinic keratosis (AK), 3 of basal cell carcinoma (BCC) and one of squamous cell carcinoma (SCC) were identified clinically and histopathologically. While, a total of 130 AK, 9 of BCC and 2 of SCC were identified in le Island. The annual prevalence of AK per J00,000 population in Kasai city during 1992 through 1997 were 413.4, 291.2, 203.7, 86.8, 123.l and JOl.8 respectively. However, those of AK in le Island during 1993 through 1997 were 1,159.4, 572.8, 1,014.3, 988.9 and 612.5 respectively. These values were significantly higher than those of Kasai City. The annual age-adjusted odds ratios for $A K$ was 2.79, 1.38, 2,45, 2.39 and 2.01 respectively. The mean prevalence of non-mela.'loma skin cancer (NMSC BCC and SCC) in le island during study period was 50.0 for men and women. The total cases of BCC and SCC in Kasai City during 1992 through 1997 were 3 and 1 respectively, too small to calculate prevalence and incidence of NMSC. Subjects with seborrheic keratosis (SK) over 6 showed a higher prevalence of AK than those with seborrheic keratosis under 5. These results indicate a strong inverse relationship between prevalence and incidence of pre-cancer and latitude among Japanese. Further, NMSC prevalence in le Island is as high as that of Japanese who live in Hawaii, suggesting a higher incidence of NMSC of Japanese even in the northern part of Japan when ozone severely decreased in the future. Skin type I and subjects with multiple (SK) were suggested to be riskfactors for skin cancer of Japanese.
\end{abstract}

Keywords: non-melanoma skin cancer, actinic keratosis, epidemiology, ultraviolet light, risk/actor.

A large body of evidence has been accumulated supporting a role of sunlight to induce skin cancer in

\footnotetext{
${ }^{1}$ Department of IJermatology, Kobe University School of Medicine, Kobe 650-0017, Japan

${ }^{2}$ Department of Preventive Medicine, Nagoya University School of Medicine, Nagoya 466-8550, Japan

${ }^{3}$ Department of Anatomic Pathology, Faculty of Medicine, University of Indonesia, Jakarta J0430, Indonesia
}

hu mans. ${ }^{1}$ Studies directly demonstrating a role of ultraviolet light in relevance to action spectra, time dose responses and host immunity in UV carcinogenesis have been mostly limited to model experiments using small animals, largely due to impracticability of these experiments in man. Therefore, epidemiological evidence showing the association of sunlight with skin cancer is of extreme importance. 
Epidemiological evidence comes from both descriptive studjes in populations and analytical studies including estimates of exposure to solar radiation in individuals and life style including food.

incidence or mortality of non-melanoma skin cancer (NMSC) is inversely related to latitude in popul ation s with light skin color. Light-skinned people born in or immigrated to Australia before 10 years of age have higher incidence rate of NMSC and melanoma than the people immigrated after 10 years of age to Australia from Europe, suggesting a role of exposure during childhood in skin cancer development. Another important evidence is that skin cancer occurs mainly at sun-exposed areas of the skin and in people who bum easily and tan poorly possibly due to higher yield of DNA damage. Xerodenna piqmentosum (XP) patients with reduced DNA repair capacity develop many cancers and show earl onset of skin cancers confined to sun-exposed skin $\cdot{ }^{4}$ A depletion of the atmospheric ozone layer results in an increase of harmful UVB flux and annual dose al ground level. ${ }^{5}$ This may in turn reults in an increase in skin cancers and precancerous lesions on sun-exposed skin. $^{6}$

Epidemiological studies on skin cancer, however, were primarily conducted to elucidate the incidence rate in light-skinned Caucasians. To our knowledge, there is no detailed report about skin cancer incidence or prevalence on sun-exposed area in Asian including Japanese, except disease rate, or incidence rate calculated from mortality rate or incomplete registration, since sunlight was not evaluated as a major cause of skin cancer of Japanese.

Tada and Miki $^{7}$ (1984) showed an increase m Japanese skin cancer patients through a survey of patients who visited Japanese university hospitals in Japan between 1971 and 1975 by comparing their data with Miyaji's'survey8 in the 1960s which was the first epidemiological study on Japanese skin cancer surveyed by a large number of patients visited dermatology clinics of university hospitals in Japan. Tada and Miki showed an apparent increase in basal cell carcinoma (BCC) in comparison with squamous cell carcinoma (SCC).

First, we conducted a survey on the frequency of NMSC and precancerous lesion in sun-exposed areas in Japanese, by analyzing the patients who visited the dermatology department of 27 Japanese uni versity hospitals. ${ }^{9}$ The objective of the study was to elucid ate a reliable skin cancer frequency in Japanese and to clarify the trend in skin cancer frequency over the last two decades. Next, we have conducted a screening for skin cancer in Kasai City ${ }^{1011}$ which is located almost at the center of Japan at $34^{\circ} 56^{\prime} \mathrm{N}$, since 1992, and in le Island, Okinawa Prefecture, ${ }^{12}$ located at $25^{\circ}$ $10^{\prime} \mathrm{N}$, since 1993 . We determined the preval ence rate of NMSC and actinic keratosis (AK) of Japanese by health examination. Participants in regional health examination were seen by dermatologists. Final diagnosis was made histopathologically. Participants were also interviewed by means of a questionnaire .

\section{MATERIALS AND METHODS}

\section{Survey on disease rate}

The hospital records of the patients with BCC, SCC and pre-cancer lesion, AK were analyzed in 27 university hospitals in Japan. The age and sex of the patients and site of the tumor were collected in each disease for the 1976-80 and 1980-90 intervals. For comparative evaluation of disease rate in two periods, age- and sex-standardized disease rates were calculated for each type of tumor by direct method, using the populations in 1979 and 1989 as the standards for 1976-80 and for 1986-90, respectively. The analyses were as follows: the disease rate in each university hospitals based on the total number of outpatients during each period: the disease rate per 100,000 population adjusted for age and sex during each period: and the rate of BCC, SCC and AK in northern and southern parts of Japan.

Skin cancer examination at Kasai City and le Island

Screening of skin cancers and pre-cancerous lesions in two locations, Kasai city situated in the central part of Japan and le Island, Okinawa, were conducted as a part of the program to screen for any cancers and other common diseases of the aged. Residents aged 20 and over were registered under the Health Science's Law for the Aged. Questionnaires asking information on name, age, sex, address, telephone number, skin type, use of cosmetics and sunscreen on sun-exposed skin, occupational sun exposure (outdoor or indoor), acute sunburns during childhood, smoking habit, location of any skin tumors, past history and treatments for cutaneous disorders. Skin types were categori zed from I to III, based on the criteria of Satoh and Kawada. ${ }^{1}$ 
Participants were examined for skin cancers and precancer lesions (AK) on the face, neck, extensor surface of the forearms and back of the hands, and for benign tumor (seborrheic keratosis: SK) on the face. Age- and sexstandardized prevalence and incidence rates for AK were calculated by the direct method, using the Japanesc"population in 1990 as the standard. The incidence of AK was calculated for people who had participated in the screening consecutively for two years in :Kasai City from 1992 through 1997, and in le Island from 1993 through 1997, respectively. Sex-and age-specific pvalence and incidences were calculated with SAS computer program (PC-SAS, 1987).

The differences in AK prevalence and incidence among people having different skin types, occupational exposure, cosmetic or sunscreen use, and severe acute sunburn at childhood and being a smoker or non-smoker, were estimated by the chi-square test. Numbers of SK on the face were counted and classified into two groups: subjects having 6 or more SK or subjects having 5 or less. The statistical significance of SK in relevance to AK was also analyzed by the chi-square-test.

\section{RESULTS}

Disease rate of SCC, BCC and AK

The disease rates of SCC, BCC and AK in university hospitals of Japan showed an increasing trend with - decreasing latitude, except in Sapporo and were higher in 1986-90 than in 1976-80. The rates of BCC and AK were significantly $(<0.001)$ higher in 1986-90 than in 1976-80, whereas there was no significant difference of SCC rate between two terms. No significant differences were seen for skin tumors of unexposed body sites.

When the hospitals were divided into those in location more than and less than $35^{\circ} \mathrm{N}$, the rates of all three types of skin tumors were higher in hospitals in the south than in the north of $35^{\circ} \mathrm{N}$. Significantly higher rates of BCC and AK were again found in 1986-90 than in 1976-80 in both locations, while that of SeC was not significantly lower in the later period. The rates of all three types of skin tumors were five times higher in the Kyushu area (Kurume, Nagasaki and Miyazaki) in the southern part of Japan than in the northern Tohoku area (Hirosaki, Sendai and Fukushima).
Prevalence and Incidence of AK in Kasai City and in le Island

The number of participants were approximately 4,500 in Kasai City and about 1,000 on le Island every year throughout the study period. Ages of the participants ranged between 20 and 97 years old in Kasai City and between 20 and 101 years old on le Island. A total of 128 cases of AK (86 males, 42 females), 3 BCC (all male) and 1 Sec (a male) were identified histopathologically in Kasai City during the 6 year period from 1992 through 1997 (Table 1). On le Island, a total of 130 cases of AK (50 males, 80 females), 9 BCC and 2 SCC were diagnosed histopathologicaliy from 1993 through 1997 (Table 1). No melanomas were detected in both locations during the study. The total number of AK for each year in both locations is also listed in Table 1. The prevalence of AK in Kasai City $1992^{8}$ was found to be 413.4 per 100,000 population, the highest value obtained during the study so far, and decreased to 86.8 (the lowest value) in 1995. The prevalence of AK for men in Kasai City was significantly higher than in women each year throughout the study period. Whereas, on le Island there was no significant difference between the prevalence of $\mathrm{AK}$ in men and in women. The mean prevalence of AK per 100,000 population, calculated from the total number of AK in Kasai City from 1992 to 1997 and on le Island from 1993 to 1997 were 203.33 (281.55 for males, 120.5 for females) and 841.8 (831.2 for males, 909.7 for female) respectively (Table 2). The mean AK prevalence on le Island was about 4 times higher than that of Kasai city (Table 2). The mean incidence of AK per 100,000 Japanese residents was 148,2 in Kasai City and 659.6 on le Island, respectively (Table 3).

Comparison of AK prevalence between Kasai City and le Island

To estimate the association between the prevalence of AK in Kasai City and that of on le Island, the ageadjust odds ratio (ORs) during the study period (1993 -1997) were calculatd. ORs in 1993, 1994, 1995, 1996, and 1997 were $2.79,1.38,2.45,2.39$ and 2.01, respectively.

Skin type and AK in Kasai City and le Island

The mean incidence rates of AK in Kasai City (from 1993 to 97) per 100,000 Japanese with skin type I, II 
Table 1. Nu-mber of AK and skin cancer in Kasai City and le Island

\begin{tabular}{|c|c|c|c|c|c|c|}
\hline \multirow{2}{*}{ Year } & \multicolumn{3}{|c|}{ Kasai City } & \multicolumn{3}{|c|}{ le Island } \\
\hline & $\mathrm{AK}(\mathrm{M} / \mathrm{F})$ & BCC & sec & $\mathrm{AK}(\mathrm{M} / \mathrm{F})$ & BCC & sec \\
\hline 1992 & $36(24 / 12)$ & 2 & 0 & - & - & - \\
\hline 1993 & $34(16 / 18)$ & 1 & 0 & $37(13 / 24)$ & 5 & 1 \\
\hline 1994 & $25(19 / 6)$ & 0 & 0 & $18(7 / 11)$ & 3 & I \\
\hline 1995 & $\mathrm{I} 0\left(\begin{array}{ll}91 & 1\end{array}\right)$ & 0 & 0 & $24(11113)$ & 1 & 0 \\
\hline 1996 & $12(913)$ & 0 & 0 & 3I $(11 / 20)$ & 0 & 0 \\
\hline 1997 & $11(912)$ & 0 & I & $20(-8 / 12)$ & 0 & 0 \\
\hline Total & $128(86 / 42)$ & 3 & I & $130(50 / 80)$ & 9 & 2 \\
\hline
\end{tabular}

Table 2. Comparative study on prevalence of actinic keratosis among people in Kasai City and le Island (per 100,000 population)

\begin{tabular}{|c|c|c|c|c|c|c|}
\hline \multirow{2}{*}{ Year } & \multicolumn{3}{|c|}{ Kasai City } & \multicolumn{3}{|c|}{ le Island } \\
\hline & Man & woman & total & man & woman & total \\
\hline 1992 & 466.1 & 321.3 & 413.4 & - & - & - \\
\hline 1993 & 336.0 & 248.0 & 291.2 & 961.6 & 1387.0 & 1159.4 \\
\hline 1994 & 334.1 & 77.9 & 203.7 & 522.6 & 615.7 & 572.8 \\
\hline 1995 & 147.0 & 28.8 & 86.8 & 1072.6 & 968.2 & 1014.3 \\
\hline 1996 & 223.6 & 26.1 & 123.1 & 862.0 & 1086.4 & 988.6 \\
\hline 1997 & 181.9 & 20.7 & 101.8 & 737.4 & 491.1 & 612.1 \\
\hline Total & 281.5 & 120.4 & 203.3 & 831.2 & 909.7 & 896.4 \\
\hline
\end{tabular}

Table 3. Incidence of actinic keratosis in Kasai City and le Island

\begin{tabular}{c|c|c|c|c|c|c}
\hline \multirow{2}{*}{ Year } & \multicolumn{5}{|c|}{ Kasai City } & \multicolumn{2}{c}{ le Island } \\
\cline { 2 - 7 } & \multicolumn{2}{|c|}{ examined } & case & Incidence & examined & \multicolumn{2}{c}{ case } & incidence \\
\hline \multirow{2}{*}{1993} & 2516 & 16 & 223.6 & - & - & - \\
1994 & 2518 & 12 & 171.2 & 1118 & 14 & 734.4 \\
1995 & 2622 & 10 & 145.0 & 1014 & 15 & 637.0 \\
1996 & 2706 & 12 & $117-.3$ & 1035 & 20 & 625.5 \\
1997 & 2562 & 11 & 99.9 & 996 & 20 & 641.3 \\
\hline Total & 12924 & 61 & & 4163 & 69 & 659.6
\end{tabular}

or III were 432.9, 206.3 and 116.7, respectively and on le Island (from 1994 to 1997) were 1,193.5, 430.7 and,..396.3 respectively (Table 4). Patients with skin type I both in Kasai City and on le Island had a significant higher incidence of AK compared with skin type III $(\mathrm{p}<0.05)$.

\section{Seborrheic Keratosis and AK}

The number of seborrheic keratosis (SK) on sunexposed areas and the prevalence of AK was comparatively examined in Kasai City and at le Island. Subjects were divided into two groups, one group with 5 or less SK, and the other group with 6 or 
Table 4. Comparative study on incidence of actinic keratosis and skin type in Kasai City and Ie Island

\begin{tabular}{|c|c|c|c|c|c|c|}
\hline \multirow{2}{*}{ Year } & \multicolumn{3}{|c|}{ Kasai City } & \multicolumn{3}{|c|}{ Ie Island } \\
\hline & I & II & III & I & II & III \\
\hline 1993 & $\cdot 842.4$ & 158.8 & 0 & - & - & - \\
\hline 1994 & 393.3 & $22 \mathrm{i} .5$ & 117.2 & 933.I & 566.6 & 644.1 \\
\hline 1995 & 362.2 & 182.4 & 121.0 & 1866.2 & 444.1 & 353.1 \\
\hline 1996 & 280.6 & 288.3 & 117.3 & 1036.7 & 448.8 & 423.7 \\
\hline 1997 & 344.4 & 198.1 & 115.5 & 937.8 & 263.3 & 164.3 \\
\hline Total & 432.9 & 206.3 & 116.7 & & 430.7 & 396.3 \\
\hline
\end{tabular}

more. People having 6 or more SK showed a statistically higher prevalence of AK than those who had 5 or less, both in Kasai City and on le Island.

Severe Acute Sunburn with Blisters during Childhood and AK

Out of 105 cases of AK detected in Kasai City between 1992 and 1995, 35 AK patients had severe sunburns in their childhood, and 69 did not. Out of 3,013 participants who had experienced severe sunburns with blister formation during their childhood, 36 subjects were found to have AK. Sixty nine AK patients were found among 15,537 participants who did not experience a severe sunburn during childhood. The prevalence of AK per 100,000 Japanese with severe sunburn was 256.2, significantly higher than 78.0 of participants who had no severe sunburn

\section{Tobacco Smoking and AK}

Participants in the skin cancer study both in Kasai City (from 1996 to 1997) and on le Island (from 1996 to 1997), were asked whether they smoked or not. Out of 1,730 participants in Kasai City who smoked, 5 had AK and among 6,621 participants who did not smoke, 18 AK cases were found. In 398 participants on le Island who smoked, 10 cases of AK were found, whereas of 1,593 participants who did not smoke, 41 cases of AK were diagnosed. There was no significant difference between the prevalence of AK in smokers and non-smokers who live in Kasai City or on le Island (Table 5).
Table 5. Relationship between prevalence of AK and smoking habit

A Kasai City

\begin{tabular}{c|c|c|c|c}
\hline \multirow{2}{*}{ Year } & \multirow{2}{*}{ Smoking } & \multicolumn{2}{|c|}{ No. of } & \multirow{2}{*}{ subjects } \\
\cline { 3 - 5 } & & $\begin{array}{c}\text { cases of } \\
\text { AK }\end{array}$ & \\
\hline \multirow{3}{*}{1996} & Yes & 1019 & 3 & 142.0 \\
& No & 3185 & 9 & 164.1 \\
& Yes & 711 & 2 & 140.0 \\
& No & 3436 & 9 & 158.3 \\
& & & & \\
\hline
\end{tabular}

B. le Island

\begin{tabular}{c|c|c|c|c}
\hline \multirow{2}{*}{ Year } & \multirow{2}{*}{ Smoking } & \multicolumn{2}{|c|}{ No.of } & \multirow{2}{*}{ Prevalence• } \\
\cline { 3 - 4 } & & subjects & $\begin{array}{c}\text { cases of } \\
\text { AK }\end{array}$ & \\
\hline \multirow{3}{*}{1996} & Yes & 183 & 6 & 242.3 \\
& No & 832 & 25 & 263.9 \\
& Yes & 206 & 4 & 264.9 \\
& No & 761 & 16 & 305.0 \\
& & & & \\
\hline
\end{tabular}

- There was no statistically significance between two groups in both places

\section{DISCUSSION}

There was an extensive epidemiological evidence that support an important role for sunlight in human skin carcinogenesis. ${ }^{1415}$ Most epidemiological studies on skin cancer, however, were performed on Caucasians and showed that BCC was the most common skin 
cancer in light-skinned people. There was also strong evidence for the role of sunlight in SeC genesis.

There was little information about the incidence of NMSC in Japanese, since Japanese, who generally had darker skin than Caucasians, were believed not to develop skin cancers on sun-exposed areas, but rather to develop skin cancers on legs and other covered areas due to burn and $\mathrm{X}$-ray radiation.

The incidence of skin cancer however, was expected to have increased among Japanese, since the mean life span in Japan is now nearly 76 years for males and 84 years for females, 20 years longer than those of 40 years ago. Further, ozone depletion by chlorofluorocarbons might cause an increase in harmful UVB radiation at the earth's surface. ${ }^{16}$ Recent changes in Japanese life-styles, such as exposing the skin more to sunlight to get tanning also contributed to an increase of skin cancer.

To determine whether skin cancers and pre-cancerous lesions in Japanese had increased, we conducted a study to an2.lyze trends in the disease rate of skin cancers from 1976 to 1980 and from 1986 to 1990 at 27 university hospitals in Japan. ${ }^{9}$ The study showed that rates of BCC and AK were higher in 1986-1990 than in 1976-1980, and also that rates of BCC, SCC and AK in southern parts of Japan were about five times higher than in northern Japan. Similar studies by Miyaji8 from 1956 to 1960 and by Tada and Miki ${ }^{7}$ from 1971 to 1975 provided additional information about skin cancer characteristics in Japan, but those studies did not report the prevalence or incidence of skin cancers in Japanese. IARC reports gave an estimated skin cancer incidence of 1.5-5.0 per 100,000 Japanese in Saga, Hiroshima, Osaka and Miyagi, but there was no report showing a reliable registry for skin cancer in those areas.

We therefore initiated this study on the incidence of skin cancers and pre-cancerous lesions in Japanese in Kasai City (populated about 50,000 residents) since 1992, and on le Island (located jn the far south of Japan) since 1993. The prevalence of AK per 100,000 Japanese in Kasai City had decreased every year, from 414.3 in 1992 to 86.8 in 1995. The incidence of AK in Kasai City ${ }^{11}$ also decreased from L993 to 1997 , suggesting that our educational campaign for residents informing the adverse effects of sunlight and the efficacy of sunscreen for protection against skin cancers, might have contributed to the reduction of AK in Kasai City. We were unable to determine the prevalence or incidence of skin cancer in Kasai City, since the number of skin cancer patients was too small. Occupational exposure to the sun was suggested to be a causative factor of AK, according to the prevalence and incidence of AK in Kasai City, which showed a higher ratio in people working outdoors, compared to people working indoors. However, there was no significant difference in the prevalence of AK in people working outdoors. in Kasai City from 1995 to 1997 and on le Island throughout the study period.

Skin type I subjects of both Kasai City and le Island had a statistically higher mean prevalence of AK during the study period compared with skin type ID subjects. Our results strongly indicate the Japanese skin type I was a risk factor for AK, and possibly for NMSC in Japanese. Xerodenna pigmentosum (XP) patients , who had defective DNA repair and who had an early onset of skin cancers on sun-exposed skin in childhood, exhibit multiple common benign skin tumors (seborrheic keratosis SK) as early as one year of age on sun-exposed sites, such as the face, the backs of the hands and the extensor surfaces of the forearms. These observation on XP patients prompted us to examine the relationship between SK and AK. ${ }^{1}$ People with 6 or more SK might belong to a high risk group for AK and possibly for skin cancer, since the prevalence of AK on patients with 5 or less SK was significantly lower than patients having 6 or more. Taken together, patients who had 6 or more SK may have less efficient DNA repair than patients with 5 or less SK.

Urback et $\mathrm{al}^{18}$ found strong associations between BCC and Sec and sunburn. Hunter et $\mathrm{al}^{19}$ also showed that risk of BCC increased with a history of sunburn. Further, Marks et $\mathrm{al}^{20}$ showed that childhood exposure to sunlight plays a significant role in the development of AK. In our questionnaires, we asked whether the number of AK in Japanese correlated with severe acute sunburns during childhood. A higher prevalence of AK was observed among people who had severe acute sunburns during childhood compared with those without such severe sunburns. In our XP (type A) siblings, first diagnosed at 4 and 2 years of age, the elder sister had her first skin cancer (BCC) at 13 years of age, whereas the younger sister had her first skin cancer. (BCC) at 23 years of age. ${ }^{21}$ This suggested an important role for sun-exposure during childhood in UV carcinogenesis, possibly by shortening the lag period of skin cancer development in human skin. 
Our results thus indicate that people who worked outdoors, had skin type I and have 6 or more SKs on sun-exposed areas, were at high risk for $\mathrm{AK}$ and possibly for NMSC. Further, protection of the skin from solar UV radiation since childhood might significantly reduced the risk of SK, AK, BCC and SCC. We believe that these data might contribute to better understanding of the risk and preventive factors of skin cancers in Indonesia.

\section{Acknowledgement}

Parts of this work were supported by a Grant-in-Aid from the Ministry of Education, Science, Culture and Sports of Japan, by the research fund for the effects of Ultraviolet Ray Influence of Human Heaith from the Global Environmentai Research, Environmental Agency, and by a grand from Shinryokukai, Kobe University School of Medicine, Japan. Further, this work is supported in part by a grant from the Japanese Committee for sunlight Protection, Kyoto, Japan.

We are very grateful to Ms Emiko Miki in Kasai City and Ms Masako Namisato on le Island for their great help in the health examinations and to Ms Mariko Hibi for editorial assistance.

\section{REFERENCES}

1. Urback F. Man and ultraviolet radiation. In: Passchier WF, Bosnjakovic BFM, editors. Human Exposure to Ultraviolet Radiation Risk and Regulation. Amsterdam, New York, Oxford: Except Medical, 1987: 3-16.

2. Robbins YH, Kraemer KH, Lutzner MSA, Festoff BW, Coon HG. Xeroderma pigmentosum: An inherited disease with sun sensitivity, multiple cutaneous neoplasms and abnormal DNA repair. Ann Inter Med, 1974; 80: 221-48.

3. Ichihashi M, Fujiwara Y. Clinical and photobiological characteristics of Japanese xeroderma pigmentosum variant. Br J Dermatol, 1981; 105: 1-12.

4. Yamamura $\mathrm{K}$, Ichihashi $\mathrm{M}$, Hiramoto $\mathrm{T}$, Ogoshi $\mathrm{M}$, Nishioka K, Fujiwara Y. Clinical and photobiological characteristic of xeroderma pigmentosum complementation -group F: a review of cases from Japan. Br J Derrnatol, 1989; 121: 471-80.

5. Dahlback A, Henriksen T, Larsen SMH, Stamnes K. Biological UV-doses and the effect of an ozone layer depletion. Photochem Photobiol, 1989; 49: 621-5.

6. Urback F, Epstein JH, Forbes PD. Ultraviolet carcinogenesis: experimental, global and genetic aspects. In: Pathak MI, Harber LC, Seiji M et al, editors. Sunlight and Man. Tokyo: Tokyo Univ. Press, 1974: 259-83.

7. Tad M, Miki Y: Malignant skin tumors among dermatology patients in university hospitals of Japan. A statistical survey 1971-1975. 1 Dermatol, 1984; 11:31321.

8. Miyaji T. Skin cancers in Japan: a nation wide 5-year survey, 1956-1960. In: NCI, Conference on Biology of Coetaneous Cancer. National Cancer Institute Monograph, No.IO, 1963: 55-70.

9. Suzuki T, Ueda M, Ogata K, Horikoshi T, Munakata N and ichihashi $\mathrm{M}$ Doses of solar ultraviolet radiation correlate with skin cancer rates in Japan. Kobe J Med Sr:i, 1996; 42: 375-88.

10. Naruse K, Ueda M, Nagano T, Suzuki T, Harada S, Imaizumi K, Watanabe S, Ichihashi M. Prevalence of actinic keratosis in Japan. J Dermatol Sci, 1997; 15:183-7.

1 1. Suzukl T, Ueda M, Naruse K, Nagano T, Harada S, Imaizu mi K, Watanabe S, Ichihashi $\mathrm{M}$. Prevalence of actinic keratosis in Japan. J Dermatol Sci, 1997; 16: 74-8.

12. Nagano $T$, Ueda $M$, Suzuki $T$, Naruse $K$, Nakamura $T$, Taguchi M, Araki K, Nakagawa K, Nagai H, Hayashi K, Watanabe S, Ichihashi M. Skin cancer screening in Okinawa; Japan. J. Dermatol Sci, 1999; 19: 161-5.

13. Satoh Y, Kawada A. Action spectrum for melani $n$ pigmentation to ultraviolet light, and Japanese skin typing. In: Fitzpatrick TB, Wick MM, Tada K (eds). Brown Melanoderma: Biology and Disease of Epidermal Pigmentation. Tokyo: Tokyo Univ. Press, 1986: 87-95.

14. Hunter DJ, Colditz GA, Stampfer MJ, Rosner B, Willett VIC, Speizer FE. Risk factors for basal cell carcinoma in a prospective cohort of women. Ann Epidemiol , 1990; 1: 13-23.

15. Elwood JM, Gallagher RP, Hill GB, Pearson JC. Cutaneous melanoma in relation to intermittent and constant sun exposure-the Western Canada Melanoma Study. Int J Cancer, 1985; 35: 427.

16. Slaper H, Velders GJM, Daniel JS, de Gruijl FR, van der Leu n JC. Estimates of ozone depletion and skin cancer incidence to examine the Vienna Convention achievements. Nature, 1996; 384: 256-8.

17. Kraemer KH, Lee MM, Scott J. Xeroderma pigmentosum: coetaneous, ocular and neurologic abnormalities in 830 published cases. Arch Dermatol, 1987; 123: 241-50.

18. Urbach F, Rose DB, Bonnem M. Genetic and environmental interactions in skin carcinogenesis. In: Proceedings of the $24 \mathrm{~h}$ Annual Symposium on Fundamental Cancer Research. Environmental Cancer. Baltimore, MD(US): Williams \& Wilkins for University of Texas, Houston, 1972: 355-71.

19. Hunter DJ, Colditz GA, Stampfer MJ, Rosner B, Willett WC, Spiezer FE. Risk factors for basal cell carcinoma in a prospective cohort of women. Ann Epidemiol, 1991; 1: 13-23.

20. Marks R, Jolley Dm, Lectsas S and Foley P. The role of childhood exposure to sunlight in the development of solar keratoses and non-melanocytic skin cancer. Med J Australia, 1990; 152: 62-6.

21. N, Triaspolitica. "Mengenal Penyakit Kanker, Jenis, Gejala, Penyebab Berikut Pengobatan Kanker." $\underline{\mathbf{M a}}$ Nanya Dong Dok. N.p, 20 June 2017. Web. 28 June 2017. <https://nanyadongdok.blogspot.com/2017/06/ mengenal-penyakit-kangker-jenis-gejala.html> . 